\title{
Effects of placentophagy on serum prolactin and progesterone concentrations in rats after parturition or superovulation
}

\author{
M. S. Blank* and H. G. Friesen \\ Department of Physiology, University of Manitoba, 770 Bannatyne Avenue, Winnipeg, \\ Manitoba, Canada R3E OW3
}

\begin{abstract}
Summary. In rats that were allowed to eat the placentae after parturition concentrations of serum prolactin were elevated on Day 1 but concentrations of serum progesterone were depressed on Days 6 and 8 post partum when compared to those of rats prevented from eating the placentae. In rats treated with PMSG to induce superovulation serum prolactin and progesterone values were significantly $(P<0.05)$ elevated on Days 3 and 5 respectively, after being fed $2 \mathrm{~g}$ rat placenta/ day for 2 days. However, feeding each rat $4 \mathrm{~g}$ placenta/day significantly $(P<0.02)$ lowered serum progesterone on Day 5. Oestrogen injections or bovine or human placenta in the diet had no effect. The organic phase of a petroleum ether extract of rat placenta ( 2 g-equivalents/day) lowered peripheral concentrations of progesterone on Day 5, but other extracts were ineffective. We conclude that the rat placenta contains orally-active substance(s) which modify blood levels of pituitary and ovarian hormones.
\end{abstract}

\section{Introduction}

The ingestion of the placenta after the birth of the fetus is a distinct maternal behaviour common to many non-human mammals (Lehrman, 1961). This placentophagy is a compulsive act; e.g. the puerperal rat largely ignores her young during the eating of the placenta. Although Denenberg, Grota \& Zarrow (1963) attach adaptive significance to placentophagy in the rat, the behaviour is poorly understood and no satisfactory, overall hypothesis regarding its physiological significance has yet been proposed (Kristal \& Graber, 1976).

Nevertheless, some studies (Denenberg et al., 1963; Grota \& Eik-Nes, 1967; Zarrow, Denenberg \& Sachs, 1972) suggest that the rat placenta contains an orally-active luteotrophic substance, possibly oestrogen. Zarrow, Grota \& Denenberg (1967) and Zarrow et al. (1972) argue that ingestion of large quantities of oestrogen at parturition could stimulate prolactin secretion, which in turn could trigger lactation and stimulate ovarian progesterone secretion.

The present investigation was undertaken to determine the effect of placentophagy on circulating levels of prolactin or progesterone, and to characterize factors in the placenta which would alter the secretion or metabolism of these hormones.

* Present address: Yerkes Regional Primate Research Center, Emory University, Atlanta, Georgia 30322, U.S.A. 


\section{Materials and Methods}

\section{Treatments}

Lactating rats. Sprague-Dawley rats were obtained from Biolab Corporation, St. Paul, Minnesota, U.S.A. The animals arrived in our animal facility when they were 10 days pregnant (Day 1 = day spermatozoa were detected in the vaginal smear); they were maintained at $22 \pm 1^{\circ} \mathrm{C}$ on a daily light:darkness cycle of $14 \mathrm{~h}$ light $(07: 00-21: 00 \mathrm{~h}) / 24 \mathrm{~h}$ and they were allowed free access to water and Wayne rat chow. On the 18th day of pregnancy, the rats were placed in individual, clear plastic cages containing wood shavings. On the day of parturition (Day 22 or 23 of gestation), placentae were plucked away with a $26 \mathrm{~cm}$ haemostat from mothers in the experimental group (Group 1E) before they could eat them. Control rats (Group 1C), littering on the same day, were allowed to eat their placentae. Mothers in both groups nursed an average of 8-10 young and, except for bleeding periods, they were continuously exposed to the young.

At $2 \mathrm{~h}$ after the last offspring was born, the mothers were bled from the retro-ocular sinus within 2 min of exposure to ether anaesthesia. On the 1st, 2nd, 4th and 6th days of lactation, between 10:00 and 12:00 h, the mothers were again bled by retro-ocular puncture under ether anaesthesia and the young were weighed (using gloved hands). On the 8th day, the mothers were decapitated, trunk blood was collected and the young were weighed. The times of bleedings after placentophagy were based on a report by Grota \& Eik-Nes (1967).

Immature rats. Female Sprague-Dawley rats were obtained from Biolab at 23 days of age. The rats were kept in wire cages (5-6 rats/cage) and maintained as described above for pregnant rats. At 28 days of age $(17: 00 \mathrm{~h})$ each rat was induced to superovulate by subcutaneous injection of 50 i.u. PMSG (Gestyl: Organon, Montreal, Canada) dissolved in $0.9 \%(\mathrm{w} / \mathrm{v}$ ) saline. Beginning $40 \mathrm{~h}$ after the PMSG injection, the rats were denied food for $8 \mathrm{~h}$. At $48 \mathrm{~h}$ after PMSG, the rats were transferred to individual cages and offered $12 \mathrm{~g}$ of granulated chow (controls: Group 2C) or chow mixed with either term rat placentae or extracts of term placentae totalling $12 \mathrm{~g}$ (experimental: Group 2E). The placentae were obtained at Caesarian section on Day 22 of gestation. These diets were again offered to the rats $24 \mathrm{~h}$ later and feeding continued for as long as $64 \mathrm{~h}$. The food was placed in deep, metal containers attached to the backs of the cages and the rats had free access to water. At least 5 of 6 rats per group ate $75 \%$ or more of the food presented to them during each 24 -h feeding period. Rats not eating at least $75 \%$ of the food were not included in the experimental results. The rats were bled from the retro-ocular sinus at 3 , 5, 7 and 9 days after the start of the feeding treatment (Day 0). At the end of the experiment, the animals were killed, trunk blood was collected and the ovaries were removed and weighed. Some of the PMSG-treated rats were injected with $0.5-200 \mu \mathrm{g}$ oestradiol-17 $\beta /$ day for 2 days, instead of the special diets. The s.c. injections in oil were started $48 \mathrm{~h}$ after PMSG.

\section{Radioimmunoassays}

Prolactin was measured in serum by double-antibody radioimmunoassay (RIA). The RIA kit (see Neill \& Reichert, 1971) was supplied by the NIAMDD and serum prolactin levels were expressed in terms of the NIH RP-1 standard. Whenever possible, duplicate serum measurements were performed in the same assay. The interassay coefficient of variation was $6.1 \%$ for the prolactin RIA at $3.3 \mathrm{ng}$ of added standard rat prolactin/tube $(n=6)$ and the sensitivity was $2 \mathrm{ng}$ prolactin $/ \mathrm{ml}$.

Progesterone was measured in petroleum ether extracts by RIA (Orczyk, Hichens, Arth \& Behrman, 1974). The radioactive ligand was $\left[1,2,6,7-{ }^{3} \mathrm{H}(\mathrm{N})\right]$ progesterone (sp. act. $114 \mathrm{Ci} / \mathrm{mmol}$ : New England Nuclear Corp., Boston, Massachusetts). The rabbit antiserum (No. 301) to progesterone exhibited $0.1 \%$ cross-reaction with $20 \alpha$-hydroxy-4-pregnen-3-one (20 $\alpha$-dihydroprogesterone). Moreover, 66-100\% of added [ ${ }^{3} \mathrm{H}_{\text {Lprogesterone }}(<2000$ c.p.m.) and $88-104 \%$ of 
added unlabelled progesterone (25-200 ng) were recovered from serum extracted with petroleum ether.

\section{Tissue extraction}

Term rat placentae were extracted as described below and were fed to rats at the rate of 4 g-equivalents/rat/day.

Total lipid extract. Placentae were extracted with chloroform and methanol according to the method of Bligh \& Dyer (1959). The methanol-water phase was dried under vacuum at $50^{\circ} \mathrm{C}$ in a rotary distiller-evaporator and the chloroform phase was dried under a stream of nitrogen at $37^{\circ} \mathrm{C}$. The dried extracts were redissolved in a small volume of $100 \%$ ethanol and then in distilled water containing $1 \%$ gelatin, such that the final ethanol concentration was $1-2 \%$. The reconstituted extracts were then added to granulated rat chow and stored at $4^{\circ} \mathrm{C}$ overnight.

Oestrogen extract. Placentae were extracted with ethanol followed by methanol according to the procedure described by Choong \& Raeside (1974). The extracts were evaporated under vacuum at $45^{\circ} \mathrm{C}$ in a rotating evaporator, and the final methanol extract was eluted and combined with rat chow as described above.

Petroleum ether extract. Rat placentae $(100 \mathrm{~g})$ were homogenized in $100 \mathrm{ml}$ distilled water at top speed with a Brinkmann homogenizer (Polytron). The homogenate was centrifuged at $15000 \mathrm{~g}$ for $30 \mathrm{~min}$ at $4^{\circ} \mathrm{C}$; the resulting supernatant was extracted 3 times with equal volumes of petroleum ether in a separatory funnel. The organic phases were pooled and dried under nitrogen at $37^{\circ} \mathrm{C}$. The dried extract was reconstituted as above and both phases were added to rat chow.

\section{Data analysis}

The data were analysed by two-way analysis of variance with repeated measures (Jenrich \& Sampson, 1979) followed by post-hoc testing (Snedecor \& Cochran, 1967), or by Student's $t$ tests.

\section{Results}

\section{Lactating rats}

Prolactin concentrations in the serum of females in Group 1E were significantly lower $(P<0.025)$ than values in control rats (Group $1 C)$ on Day 1 (Table 1). Serum prolactin values on Day 1 rose at least $100 \%$ in 5 of 6 of the control rats but in only 1 of 7 of those in Group $1 \mathrm{E}$. In fact, 4 of 7 Group $1 \mathrm{E}$ females had lower prolactin levels on Day 1 than shortly after parturition. A difference in serum progesterone between the two groups was evident early in lactation and values were significantly higher by Day 6 in the Group 1E females and continued to rise by Day 8 .

\section{Immature rats}

PMSG-primed rats that were fed $2 \mathrm{~g}$ placenta/day $(\mathrm{N}=12)$ in pilot studies had higher $(P<0.05)$ levels of serum prolactin $(112 \pm 14$ (s.e.m.) $\mathrm{ng} / \mathrm{ml})$ than did chow-fed controls $(74 \pm 11 \mathrm{ng} / \mathrm{ml}, \mathrm{N}=13)$ on Day 3 and elevated $(P<0.05)$ levels of serum progesterone $(411 \pm 29, N=6$, and $258 \pm 30, N=5$ respectively) on Day 5 . Differences in serum prolactin or progesterone were not evident at other times between Days 3 and 9 .

Day 5 was therefore chosen as the end-point for subsequent studies of the effects of placental ingestion on serum progesterone (Table 2). A placental content of $4 \mathrm{~g} / \mathrm{rat} / \mathrm{day}$ produced a 
Table 1. Serum hormone concentrations in lactating rats allowed to eat (Group 1C) or prevented from eating (Group $1 \mathrm{E}$ ) their placentae at parturition

\begin{tabular}{|c|c|c|c|c|}
\hline \multirow[b]{2}{*}{ Time post partum } & \multicolumn{2}{|c|}{$\begin{array}{c}\text { Prolactin } \\
(\mathrm{ng} / \mathrm{ml})\end{array}$} & \multicolumn{2}{|c|}{$\begin{array}{l}\text { Progesterone } \\
(\mathrm{ng} / \mathrm{ml})\end{array}$} \\
\hline & Group 1C $(N=6)$ & Group 1E $(\mathrm{N}=7)$ & Group 1C $(N=6)$ & Group $1 \mathrm{E}(\mathrm{N}=7)$ \\
\hline $2 \mathrm{~h}$ & $91 \pm 59$ & $234 \pm 121$ & - & - \\
\hline 1 day & $234 \pm 55$ & $77 \pm 22^{*}$ & $8 \cdot 5 \pm 2 \cdot 3$ & $11.9 \pm 4.3$ \\
\hline 2 days & $554 \pm 176$ & $322 \pm 90$ & $10.5 \pm 1.3$ & $14 \cdot 2 \pm 4 \cdot 2$ \\
\hline 4 days & $502 \pm 39$ & $515 \pm 96$ & $33.4 \pm 4.6$ & $39.6 \pm 5.0$ \\
\hline 6 days & $375 \pm 81$ & $664 \pm 203$ & $49.7 \pm 5.1$ & $66.9 \pm 4.3 \dagger$ \\
\hline 8 days & $394 \pm 86$ & $640 \pm 171$ & $57.2 \pm 8.3$ & $98.9 \pm 8.1 \mp$ \\
\hline
\end{tabular}

Values are mean \pm s.e.m.

* $P<0.025$ compared with value for Group 1C (Student's $t$ test, because of increased variability later in lactation).

$\dagger P<0.05, \ddagger P<0.01$ compared with equivalent values in Group 1C (post-hoc testing).

Table 2. Serum progesterone concentrations in PMSG-treated rats on the 5th day after the start of various feeding regimens

\begin{tabular}{|c|c|c|c|}
\hline Substance fed & $\begin{array}{l}\text { No. of } \\
\text { rats }\end{array}$ & $\begin{array}{l}\text { Wt of placentae or } \\
\text { placental equivalents } \\
\text { fed to each rat } \\
\text { (g) }\end{array}$ & $\begin{array}{l}\text { Progesterone } \\
\text { (ng/ml) }\end{array}$ \\
\hline Chow, control & 16 & - & $371 \pm 24$ \\
\hline Rat placentae & 12 & 2 & $456 \pm 34^{*}$ \\
\hline Bovine placenta & 7 & 2 & $288 \pm 29$ \\
\hline Human placenta & 7 & 2 & $290 \pm 32$ \\
\hline Rat placentae (term) & 5 & 4 & $248+25^{* *}$ \\
\hline \multicolumn{4}{|l|}{ Petroleum ether extract } \\
\hline Organic phase & 6 & 4 & $230 \pm 71^{*}$ \\
\hline Aqueous phase & 6 & 4 & $314 \pm 34$ \\
\hline Ethanol-methanol extract & 6 & 4 & $367 \pm 27$ \\
\hline \multicolumn{4}{|l|}{ Total lipid extract } \\
\hline Methanol-water phase & 6 & 4 & $349 \pm 60$ \\
\hline Chloroform phase & 6 & 4 & $336 \pm 27$ \\
\hline
\end{tabular}

Values are mean \pm s.e.m.

${ }^{*} P<0.05,{ }^{* *} P<0.02$ compared with value for controls fed chow only.

decrease in serum progesterone on Day 5, and so did the organic phase of a petroleum ether extract of rat placenta, whereas the total lipid (chloroform-methanol) or oestrogen (ethanolmethanol) extracts did not affect progesterone concentrations. Diets containing whole bovine or human placenta tissue $(2 \mathrm{~g} / \mathrm{rat} / \mathrm{day})$ did not alter serum progesterone values and oestradiol injections were also ineffective.

\section{Discussion}

The endocrine consequences of placentophagy in the rat may affect the return to a normal oestrous cycle. For example, in the absence of placentophagy serum levels of progesterone were elevated on Days 6 and 8 post partum compared with values in animals allowed to eat the placentae. Since progesterone is probably responsible for maintaining gonadotrophin levels below cyclic values in intact, lactating rats (Smith \& Neill, 1977), progesterone should be relatively low for a normal return to cyclicity. The suppression of progesterone levels by placentophagy may therefore facilitate the onset of subsequent oestrous cycles. These data are 
at variance with those of Grota \& Eik-Nes (1967) who reported decreased levels of serum progesterone on the 4th day post partum in rats prevented from eating the placentae. We conclude that ingestion of the placenta at term is not luteotrophic in the rat.

Prolactin concentrations differed only on Day 1 post partum but the stimulation of prolactin secretion (by placentophagy?) early in lactation could provide an initial trigger which prevents progesterone levels from rising prematurely to cyclic values. The pattern of maternal prolactin concentrations during lactation reported here is comparable to that reported by others (Labhsetwar \& Watson, 1974; Bohnet, Gomez \& Friesen, 1977), but the higher values in the present study could be related to uninterrupted suckling by the young (Stern \& Voogt, 1973) and the retro-ocular bleeding site (Döhler et al., 1978).

We can only speculate on how placentophagy might stimulate prolactin secretion early in lactation while inhibiting progesterone levels 6 days later. A humoral factor from the placenta could initiate post-partum maternal and, possibly, suckling behaviours (Terkel \& Rosenblatt, 1972). This behaviour might then maintain serum prolactin levels which, in combination with suckling itself, could inhibit gonadotrophin secretion (Smith \& Neill, 1977) and prevent an early rise in progesterone levels. Alternatively, denial of placentae at term could have disrupted normal suckling (Rosenblatt, 1975) thereby altering serum prolactin levels. This would account for the lower levels of prolactin in the experimental females on Day 1. Nevertheless, suckling behaviour appeared normal and the weight gains of the young in both groups were similar.

The effect of the larger amount $(4 \mathrm{~g})$ of placenta fed to PMSG-treated rats is consistent with the idea that placentophagy may prevent the post-partum rise in serum progesterone concentrations. Furthermore, this daily amount corresponds to the placental intake of a parturient female, with 8-12 young, but the entirely opposite effect of $2 \mathrm{~g}$ rat placenta cannot be explained. The lack of effect of whole bovine or human placenta indicates species-specificity. The organic phase of a petroleum ether extract of rat placenta induced a lowering of serum progesterone similar to that of whole placenta but the activity was not present in other steroid or lipid extracts. Furthermore, oestrogen injections failed to induce significant changes in serum progesterone concentrations. These findings suggest that the placental substance which modified blood levels of pituitary and ovarian hormones is not oestrogen or an oestrogenic steroid, as others have proposed (Denenberg et al., 1963).

We thank Dr Hal Behrman for the progesterone antiserum (\#301), Dr Daniel Grinwich and Dr Steven Moffit for valuable discussion, the NIAMDD and Dr A. F. Parlow for the rat prolactin radioimmunoassay kit, and Ms Jean Torbit for typing our manuscript. This research was supported by grants from the MRC of Canada and the USPHS Child Health and Human Development, No. 07843-05.

\section{References}

Bligh, E.G. \& Dyer, W.J. (1959) A rapid method of total lipid extraction and purification. Can. J. Biochem. Physiol. 37, 911-917.

Bohnet, H.G., Gomez, F. \& Friesen, H.G. (1977) Prolactin and estrogen binding sites in the mammary gland of the lactating and non-lactating rat. Endocrinology 101, 1111-1121.

Choong, C.H. \& Raeside, J.I. (1974) Chemical determination of oestrogen distribution in the foetus and placenta of the domestic pig. Acta endocr., Copenh. 77, 171-185.

Denenberg, V.H., Grota, L.J. \& Zarrow, M.X. (1963) Maternal behaviour in the rat: analysis of crossfostering. J. Reprod. Fert. 5, 133-141.
Döhler, K.-D., Wong, C.C., Gaudssuhn, D., von zur Muhlen, A., Gärtner, K. \& Döhler, U. (1978) Site of blood sampling in rats as a possible source of error in hormone determinations. $J$. Endocr. 79, 141142.

Grota, L.J. \& Eik-Nes, K.B. (1967) Plasma progesterone concentrations during pregnancy and lactation in the rat. J. Reprod. Fert. 13, 83-91.

Jenrich, R. \& Sampson, P. (1979) Analysis of variance and covariance including repeated measures, In BMDP Biomedical Computer Programs, pp. 540580. Eds W. J. Dixon \& M. B. Brown. University of California Press, Berkeley.

Kristal, M.B. \& Graber, G.C. (1976) Placentophagia in 
nonpregnant rats: infuence of estrous cycle stage and birthplace. Physiol. Behav. 17, 599-605.

Labhsetwar, A.P. \& .Watson, D.J. (1974) Temporal relationship between secretory patterns of gonadotrophins, estrogens, progestins and prostaglandinF in periparturient rałs. Biol. Reprod. 10, 103-110.

Lehrman, D.S. (1961) Hormonal regulation of parental behavior in birds and infrahuman mammals. In Sex and Internal Secretions. Vol. II, p. 1312. Eds W. C. Young \& G. S. Corner. Williams \& Wilkins, Baltimore.

Neill, J.D. \& Reichert, L.E. (1971) Development of a radioimmunoassay for rat prolactin and evaluation of the NIAMD rat prolactin radioimmunoassay. Endocrinology 88, 548-555.

Orczyk, G.P., Hichens, M., Arth, G. \& Behrman, H.R. (1974) Progesterone. In Methods of Hormone Radioimmunoassy, pp. 347-358. Eds B. M. Jaffe \& H. R. Behrman. Academic Press, New York.

Rosenblatt, J.S. (1975) Prepartum and postpartum regulation of maternal behaviour in the rat. $C I B A$ Fdn Symp. 33, 17-37.
Smith, M.S. \& Neill, J.D. (1977) Inhibition of gonadotropin secretion during lactation in the rat: relative contribution of suckling and ovarian steroids. Biol. Reprod. 17, 255-261.

Snedecor, G.W. \& Cochran, W.G. (1967) Statistical Methods. Iowa State University Press, Ames.

Stern, J.M. \& Voogt, J.L. (1973) Comparison of plasma corticosterone and prolactin levels in cycling and lactating rats. Neuroendocrinology 13, 173-181.

Terkel, J. \& Rosenblatt, J.S. (1972) Humoral factors underlying maternal behavior at parturition. $J$. comp. Physiol. Psychol. 80, 365-371.

Zarrow, M.X., Grota, L.J. \& Denenberg, V.H. (1967) Maternal behavior in rat: survival of newborn fostered young after normal treatment of the foster mother. Anat. Rec. 157, 13-18.

Zarrow, M.X., Denenberg, V.H. \& Sachs, B.D. (1972) Hormones and maternal behavior in mammals. In Hormones and Behavior, pp. 120-123. Ed. S. Levine. Academic Press, New York.

Received 26 November 1979 